\title{
Viral dynamics in two trophically different areas in the Central Adriatic Sea
}

\author{
Marin Ordulj ${ }^{*} \mathbb{B}$, Nada Krstulović ${ }^{2}$, Danijela Šantić2, Slaven Jozić ${ }^{2}$ and Mladen Šolić ${ }^{2}$
}

\begin{abstract}
To understand the activity of marine viruses, experiments on viral production, viral decay and the percentage of lytic and lysogenic bacterial cells among the total number of bacterial cells were carried out seasonally at two stations in the Adriatic Sea with different trophic conditions. Additionally, we are providing an insight on the enrichment with dissolved and particulate organic matter by viral lysis in the studied area. Viral production was higher at the coastal station than at the open-sea station. Viral decay rates were also higher at the coastal sea station than at the open-sea station, and accounted for approximately $40 \%$ of viral production at both investigated stations. The percentage of lysogenic infection was lower than that of lytical infection, which indicates the prevalence of the lytic cycle at both stations. Viruses had a significant influence on bacterial mortality through high daily removal of the bacterial standing stock at the coastal and open-sea station. The viruses contributed to the restoration of dissolved organic carbon, nitrogen and phosphorus in the microbial loop by lysing the bacterial cells at the studied stations. All the above suggest that viruses are important in the microbial food web and an important factor in the control of bacterial populations within the study area.
\end{abstract}

Keywords: Marine viruses, Bacteria, Viral production, Viral decay, Lysogeny

\section{Introduction}

Viruses are the most abundant and ubiquitous component of marine microbial plankton, and the major cause of bacterial mortality, since bacteria are thought to be their main hosts [1-5]. Viral abundance exceeds the abundance of their bacterial host by approximately 25 times, but this value may vary, generally from 3 to 100 , due to different environmental conditions $[3,6]$. In nutrientrich and more productive environments, the difference is expected to be greater in favour of viral abundance [6]. Viruses lyse $10-50 \%$ of bacterial standing stock per day on average [5]. This value can be even higher, depending mostly on the host density and productivity, but also on environmental conditions, such as temperature, salinity and UV radiation $[3,4,6,7]$. Additionally, virus-mediated bacterial mortality can even match grazer-mediated mortality in different marine environments $[6,8]$. The lysis of

\footnotetext{
*Correspondence: marin.ordulj@unist.hr

1 University Department of Marine Studies, University of Split, Ruđera Boškovića 37, Split, Croatia

Full list of author information is available at the end of the article
}

host cells can have a great effect on nutrient and biogeochemical cycling, by releasing large amounts of dissolved and particulate organic matter into seawater. Furthermore, the ecological effects of viral lysis are manifested via changes in bacterial community structure on the principle of the "Killing The Winner" Model, which has been reviewed previously $[4,6,9,10]$.

Viral activity and, therefore, bacterial mortality, can be affected by local trophic conditions [11-14], since marine environments with higher trophic levels usually support higher abundance and productivity of bacteria, which may result in an increase in viral numbers too. Different trophic conditions might also have a substantial impact on the way in which viruses replicate in the marine environment. In the lytic cycle, after infection, viruses use the host metabolism to replicate, which usually results in the release of the new viruses as a result of bursting of the host cell. In the lysogenic cycle, the viral genome integrates with the host genome and doubles along with the host. The incorporated "prophage" is dormant until induction occurs (when the host is stressed), and the lytic cycle is initiated. Several authors have indicated that 
lysogeny is the most favourable way of viral replication in environments with low host abundance and activity, as opposed to environments with high host abundance and activity where a lytic replication cycle prevails $[13,15-$ 17]. However, new findings suggest that lysogeny could also be favoured in environments with increased host density $[18,19]$.

Although the distribution of viruses and their relationship to other components of the microbial community in the Adriatic is well documented [11, 20-25], the activity of viruses, has been poorly studied so far. Previous research on viral dynamics has mostly been carried out in the northern Adriatic [13, 26, 27], whereas no data from other geographical areas of the Adriatic are available. The main goal of this study is to determine the potential influence of environmental trophic conditions on viral dynamics in the Central Adriatic, since evidently the nutrient-rich and more productive environments favour higher abundance of heterotrophic bacteria and, therefore, higher abundance and activity of viruses. To achieve this goal, experiments on viral production, viral decay and the percentage of lytical and lysogenic infection of bacterial cells among the total number of bacterial cells were carried out at two stations in trophically different areas of the Central Adriatic Sea. Additionally, from the viral production experiments, we estimated the role of viruses in the release of dissolved and particulate organic matter.

\section{Materials and methods}

The experiments were performed seasonally (from October 2010 to July 2011) at in situ temperatures onboard the R/V BIOS DVA at two stations with different trophic status, situated in the Central Adriatic. The coastal sea station is located in Kaštela Bay, which is under the influence of the karstic river Jadro and is mesotrophic, whereas the open-sea station is located near the island of Vis, and is characterized as oligotrophic [28] (Fig. 1). Samples for the experiments, described in detail below, were collected four times with 5 -L Niskin bottles at three depths (at the surface, the thermocline layer and the bottom), and were later transferred to 2-L sterile containers for further analyses. To detect the layer of the thermocline, water temperature and salinity were recorded prior

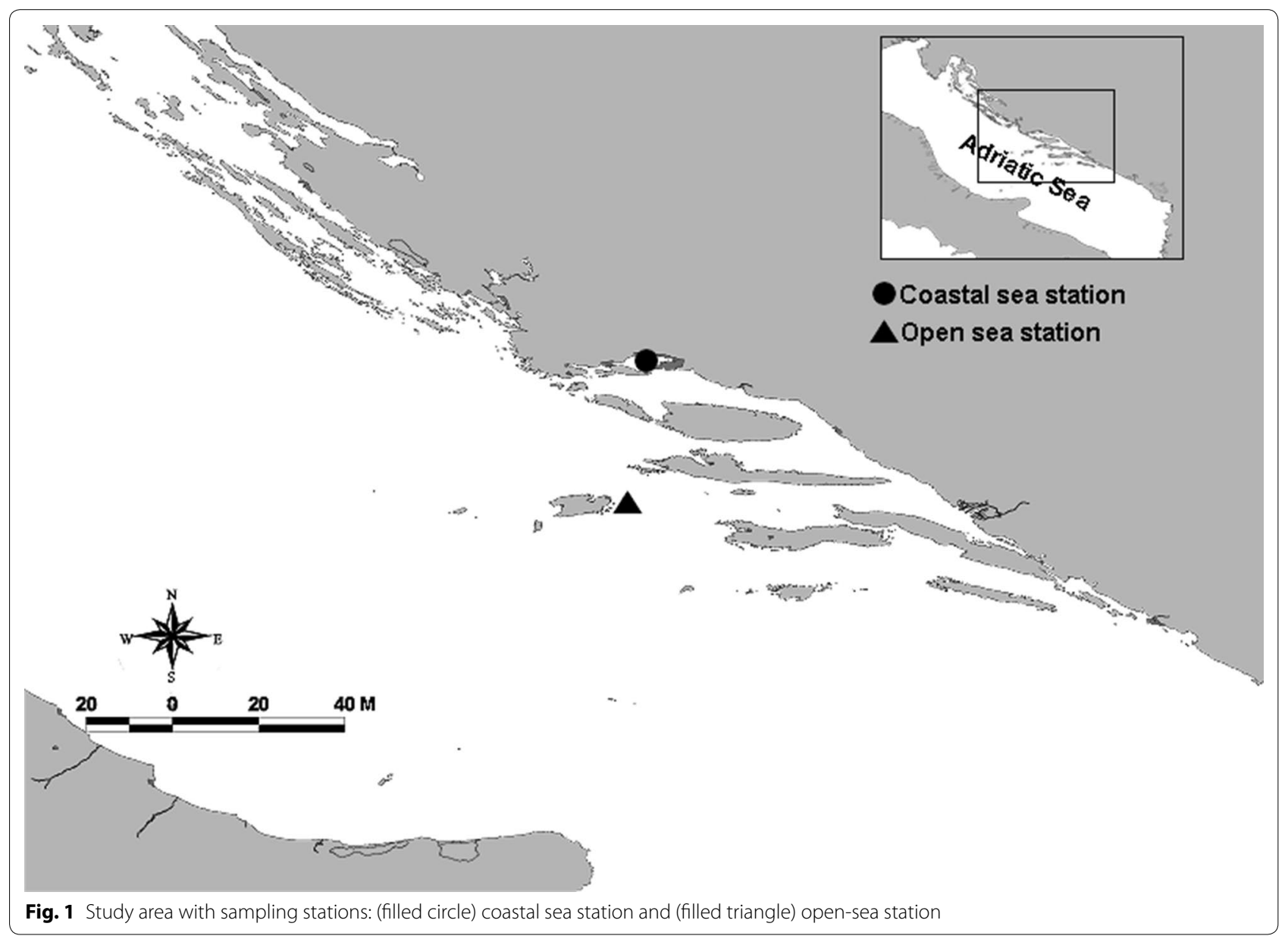


to sampling, using a SeaBird 25 CTD profiler. If the thermocline was not formed, then samples were taken from the depth of $10 \mathrm{~m}$ and are considered as the depth of the thermocline in the results.

\section{Bacterial abundance}

The abundance of marine bacteria was determined by flow cytometry as described in Marie et al. [29]. Samples $(1 \mathrm{~mL})$ were stained with SybrGreen I (stock solution diluted $100 \times$ ), and analysed using a Beckman Coulter EPICS XL-MCL (high flow rate from 1.0 to $1.2 \mu \mathrm{L} \mathrm{s}^{-1}$ ).

\section{Bacterial cell production}

Bacterial cell production was determined using the ${ }^{3} \mathrm{H}$-thymidine incorporation technique [30]. Conversion factors for bacterial production were calculated from the bacterial cell number and ${ }^{3} \mathrm{H}$-thymidine incorporation during bacterial growth in $1 \mu \mathrm{m}$ pre-filtered seawater [31]: $\mathrm{CF}=(\mathrm{N} 2-\mathrm{N} 1) /{ }^{3} \mathrm{H}$, where $\mathrm{N} 1$ and $\mathrm{N} 2$ represent the numbers of bacteria at the beginning and the end of the experiment, respectively, and ${ }^{3} \mathrm{H}$ is the integrated ${ }^{3} \mathrm{H}$-thymidine incorporation rate during the experiment.

\section{Viral abundance}

The abundance of marine viruses was determined as described in Noble and Fuhrman [32], with slight modifications. Collected samples were processed immediately without any fixative to avoid potential underestimation of virus like particles counts using formaldehyde [33]. Samples $(2 \mathrm{~mL}$ ) were filtered through $0.02-\mu \mathrm{m}$ filters (Anodisc; diameter: $25 \mathrm{~mm} ; \mathrm{Al}_{2} \mathrm{O}_{3}$, Whatman) and stained with SYBR Green I (stock solution diluted $300 \times$ ). Filters were incubated in the dark for $20 \mathrm{~min}$ and mounted on glass slides with a drop of $50 \%$ phosphate buffer $(6.7 \mathrm{mM}$, $\mathrm{pH} 7.8$ ) and $50 \%$ glycerol, containing $0.5 \%$ ascorbic acid. Slides were stored at $-20^{\circ} \mathrm{C}$ until analysis (5-10 days). Viral counts were obtained by epifluorescence microscopy (Olympus BX 51, equipped with a blue excitation filter) under $1250 \times$ magnification (objective $100 \times$, ocular $12.5 \times$ ), and are expressed as virus-like particles (vlp) per $\mathrm{mL}$.

To estimate viral production, decay, and the fraction of lysogenic cells, water samples were collected from three depths (as mentioned previously) and were transferred to 2-L sterile containers for subsequent different treatments.

\section{Viral production}

The virus dilution technique described by Wilhelm et al. [34] was used to determine viral production rates and bacterial losses due to viruses. Triplicate samples $(50 \mathrm{~mL})$ were transferred to sterile glass bottles and mixed with $100 \mathrm{~mL}$ virus-free (filtered through $0.02 \mu \mathrm{m}$ pore sized filters) seawater and were incubated in the dark at the in situ temperature. Parallel untreated samples were also incubated as a control. Subsamples of $2 \mathrm{~mL}$ were taken at the beginning of the experiment, and every $3 \mathrm{~h}$ for a $12-\mathrm{h}$ period to determine viral abundance, as previously described. Viral production rates were estimated using "VIPCAL" software from each time period with a net increase in viral abundance [35]. Turnover rates were determined by dividing viral production rates by viral abundance. The percentage of lytically infected bacterial cells was calculated from the ratio of lysed bacterial cells and the bacterial abundance as described by Weinbauer et al. [36].

\section{Burst size}

The burst size (BS), or the number of viruses released per cell due to viral lysis, was estimated from time-course experiments of viral production, as described in Wells and Deming [37], Middelboe and Lyck [38], and Boras et al. [39]. In brief, an increase in viral abundance during the incubation period was divided by a decrease in bacterial abundance for the same time period as that of the viral production experiment.

\section{Viral decay}

Viral decay rates were obtained by monitoring the changes in viral abundance in triplicate samples that were filtered through $0.2-\mu \mathrm{m}$ polycarbonate filters to exclude bacteria and $>0.2 \mu \mathrm{m}$ particles [40]. Filtered water $(200 \mathrm{~mL})$ was incubated in the dark at in situ temperature. Subsamples $(2 \mathrm{~mL})$ were taken every $3 \mathrm{~h}$ for $12 \mathrm{~h}$ and samples were immediately processed for viral counts as described previously. The decay rates were calculated from the linear regression of log-transformed data where the slope of the line is the decay constant.

\section{Fraction of lysogenic cells}

The fraction of lysogenic cells was estimated using mytomicin C (SigmaChemical Co, No. M-0503), the most effective phage inducing agent $[13,41]$. Collected seawater $(150 \mathrm{~mL})$ was placed in incubation bottles with mytomicin $C(1 \mu \mathrm{g} / \mathrm{mL}$ final concentration). The samples were incubated for $12 \mathrm{~h}$, in parallel with untreated water samples that served as control. Subsamples $(2 \mathrm{~mL})$ were collected at the beginning, after $6 \mathrm{~h}$ and subsequently, every $3 \mathrm{~h}$ until the end of the experiment. Viral and bacterial counts, as well as bacterial production were determined as described previously. The results were expressed as a percentage of lysogenic cells, as described by Paul and Weinbauer [17]. Briefly, subtraction of the viral direct counts in the experiment and viral direct counts in the control was divided by the average $\mathrm{BS}$ and then by bacterial abundance at the beginning of the experiment. 
Virus-mediated bacterial mortality

Virus-mediated bacterial mortality (VMM) was estimated as a percentage of bacterial standing stock loss per day by dividing the lysis rate of bacteria by the number of bacteria in the original sample. The lysis rate of bacteria was calculated from the ratio between viral production and burst size as described by Luef et al. [35].

\section{Release of organic carbon, nitrogen and phosphorus by viral lysis}

The amount of released carbon and nitrogen was determined by multiplying the lysis rate of bacterial cells and the mean amounts of carbon and nitrogen contained in a bacterial cell. For the released carbon content, we used a value of $20 \mathrm{fg} \mathrm{C}$ cell $^{-1}$ and for nitrogen, $4 \mathrm{fg} \mathrm{N}$ cell $^{-1}$ [35, 42-45]. The release rate of phosphorus was calculated from the ratio of carbon and phosphorus, as explained by Cole et al. [46]. The amounts of carbon, nitrogen and phosphorus released, are expressed as $\mu \mathrm{g}$ carbon/nitrogen/phosphorus per litre per day.

\section{Statistical analysis}

The correlations between parameters were expressed as Pearson correlation coefficients. Analysis of variance (ANOVA) and $t$ tests were used to assess the differences in microbiological parameters throughout the water column and between investigated stations.

\section{Results}

\section{Bacterial abundance and production}

The distribution of bacteria and bacterial production at the studied area are shown in Table 1. Bacterial abundance at the coastal station ranged from 0.40 to $0.85 \times 10^{6}$ cells $\mathrm{mL}^{-1}$, with a mean of $0.58 \pm 0.14 \times 10^{6}$ cells $\mathrm{mL}^{-1}$. At the open-sea station, bacterial abundance was two-fold lower and ranged from 0.25 to $0.34 \times 10^{6}$ cells $\mathrm{mL}^{-1}$ with a mean of $0.30 \pm 0.03 \times 10^{6}$ cells $\mathrm{mL}^{-1}$. A significant difference in bacterial abundances between sampled stations ( $t$ test, $\mathrm{p}<0.05)$ was observed. Furthermore, a significant difference between layers and seasons was observed for the

Table 1 Sampling depth and month, temperature, salinity, viral and bacterial abundance, virus-to-bacterium ratio (VBR) and bacterial production at the investigated coastal and open-sea station

\begin{tabular}{|c|c|c|c|c|c|c|c|}
\hline Depth (m) & Month & Temperature $\left({ }^{\circ} \mathrm{C}\right)$ & Salinity & Viruses* $\left(10^{6}\right.$ vlp $\left.\mathrm{mL}^{-1}\right)$ & Bacteria* $\left(10^{6}\right.$ cell $\left.\mathrm{mL}^{-1}\right)$ & VBR & $\begin{array}{l}\text { Bacterial Production* } \\
\left(10^{4} \text { cells } \mathrm{mL}^{-1} \mathrm{~h}^{-1}\right)\end{array}$ \\
\hline \multicolumn{8}{|c|}{ Coastal station, $43^{\circ} 31^{\prime} 10^{\prime \prime} \mathrm{N}, 16^{\circ} 22^{\prime} 52^{\prime \prime} \mathrm{E}$} \\
\hline 0 & 10 & 17.96 & 37.25 & 16.41 & 0.69 & 24 & 0.13 \\
\hline 0 & 2 & 11.99 & 37.16 & 14.74 & 0.56 & 26 & 0.16 \\
\hline 0 & 6 & 22.00 & 36.47 & 13.32 & 0.50 & 26 & 0.15 \\
\hline 0 & 7 & 25.33 & 37.24 & 15.80 & 0.85 & 19 & 0.48 \\
\hline 10 & 10 & 17.90 & 37.27 & 14.78 & 0.65 & 23 & 0.12 \\
\hline 10 & 2 & 11.97 & 36.93 & 14.92 & 0.56 & 26 & 0.12 \\
\hline 17 & 6 & 20.57 & 37.48 & 10.89 & 0.44 & 25 & 0.34 \\
\hline 11 & 7 & 18.46 & 38.02 & 10.69 & 0.55 & 19 & 0.11 \\
\hline 35 & 10 & 18.10 & 37.32 & 16.54 & 0.65 & 26 & 0.10 \\
\hline 35 & 2 & 13.03 & 37.93 & 12.76 & 0.74 & 17 & 0.20 \\
\hline 35 & 6 & 14.29 & 38.13 & 12.56 & 0.40 & 31 & 0.26 \\
\hline 35 & 7 & 15.04 & 38.24 & 13.24 & 0.40 & 33 & 0.08 \\
\hline \multicolumn{8}{|c|}{ Open-sea station, $43^{\circ} 2^{\prime} 39^{\prime \prime} N, 16^{\circ} 17^{\prime} 6^{\prime \prime} E$} \\
\hline 0 & 2 & 13.05 & 37.79 & 10.12 & 0.33 & 31 & 0.11 \\
\hline 0 & 6 & 22.52 & 38.66 & 6.89 & 0.30 & 23 & 0.11 \\
\hline 0 & 7 & 25.88 & 38.39 & 6.78 & 0.32 & 21 & 0.12 \\
\hline 10 & 2 & 13.10 & 37.79 & 11.18 & 0.34 & 33 & 0.11 \\
\hline 15 & 6 & 18.79 & 36.51 & 6.89 & 0.30 & 23 & 0.05 \\
\hline 20 & 7 & 19.87 & 38.53 & 6.37 & 0.30 & 21 & 0.10 \\
\hline 100 & 2 & 14.40 & 38.46 & 7.92 & 0.28 & 29 & 0.18 \\
\hline 100 & 6 & 14.66 & 38.66 & 6.22 & 0.25 & 25 & 0.11 \\
\hline 100 & 7 & 15.00 & 38.68 & 6.89 & 0.26 & 27 & 0.14 \\
\hline
\end{tabular}

* Significance of differences between two stations, $\mathrm{p}<0.05$ 
coastal- and open-sea station ( $p<0.05$, ANOVA), with higher bacterial abundances in the surface layer during the warmer part of the year. Bacterial production was higher at the coastal rather than at the open sea station $\left(0.19 \pm 0.12 \times 10^{4}\right.$ and $0.12 \pm 0.03 \times 10^{4}$ cells $\mathrm{mL}^{-1} \mathrm{~h}^{-}$ 1 , respectively). Average bacterial turnover at the coastal station was $6.60 \pm 4.11$, and $7.15 \pm 2.76 \mathrm{day}^{-1}$ at the open sea station.

\section{Viral abundance and activity}

Viral abundance ranged from 10.69 to $16.54 \times 10^{6} \mathrm{vlp} \mathrm{mL}^{-1}$ with a mean of $13.89 \pm 1.97 \times 10^{6} \mathrm{vlp} \mathrm{mL}^{-1}$ at the coastal sea station, and was significantly higher $(t$ test, $\mathrm{p}<0.05)$ than at the open sea station where it ranged from 6.22 to $11.67 \times 10^{6} \mathrm{vlp} \mathrm{mL}^{-1}$ (mean value was $7.80 \pm 1.85 \times 10^{6}$ vlp $\mathrm{mL}^{-1}$ ). Viral abundance was higher at the coastal station than at the open-sea station at all three investigated depths ( $p<0.05$, ANOVA) (Fig. 2).

The virus-to-bacteria ratio (VBR) was similar at both stations, with a mean value of about 25 (Table 1). The VBR was negatively correlated with bacterial abundance at the costal station $(\mathrm{r}=-0.79, \mathrm{n}=12, \mathrm{p}<0.05)$, and positively correlated with viral abundance at the open sea station $(\mathrm{r}=0.87, \mathrm{n}=9, \mathrm{p}<0.05)$. Viral production was higher at the coastal sea station where it ranged from 0.32 to $1.87 \times 10^{6} \mathrm{vlp} \mathrm{mL}^{-1} \mathrm{~h}^{-1}$, with

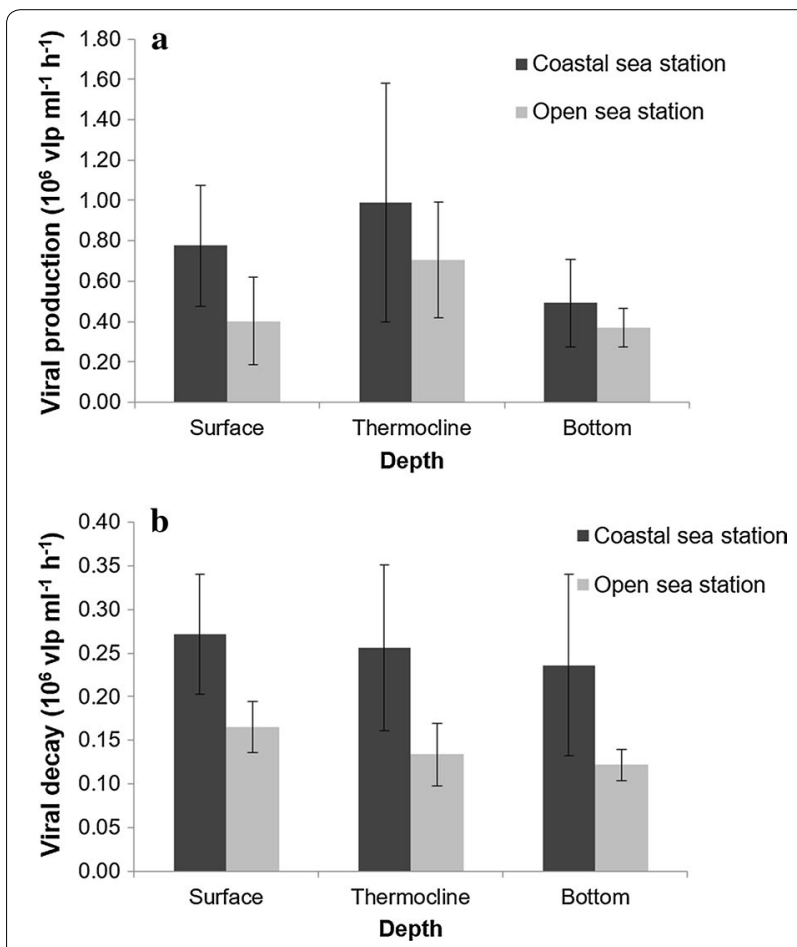

Fig. 2 Viral production (a) and viral decay (b) in the surface, thermocline and near-bottom layers at the coastal and open sea stations (annual mean values \pm SD) a mean of $0.75 \pm 0.44 \times 10^{6} \mathrm{vlp} \mathrm{mL}^{-1} \mathrm{~h}^{-1}$ (Table 2). At the open-sea station, viral production ranged from 0.15 to $0.95 \times 10^{6} \mathrm{vlp} \mathrm{mL}^{-1} \mathrm{~h}^{-1}$, with a mean of $0.49 \pm 0.26 \times 10^{6} \mathrm{vlp} \mathrm{mL} L^{-1} \mathrm{~h}^{-1}$. Viral turnover time varied from 5.01 to $56.01 \mathrm{~h}$ with a mean of $25.93 \pm 14.55 \mathrm{~h}$ at the coastal sea station, and from 6.81 to $58.62 \mathrm{~h}$ with a mean of $20.62 \pm 12.60 \mathrm{~h}$ at the open-sea station. Faster turnover time was determined during the warmer part of the year at the depths of the thermocline, when viral production was also the highest (Table 2). The BS ranged from 12 to 65 viruses per bacterial cell (mean $=41 \pm 17$ viruses per bacterial cell) at the coastal station, and from 18 to 101 viruses per bacterial cell ( mean $=62 \pm 29$ viruses per bacterial cell) at the open sea station, and were statistically different $(t$ test, $\mathrm{p}<0.05$ ). Viral decay values were higher at the coastal sea station $\left(\right.$ mean $=$ of $0.25 \pm 0.08 \times 10^{6} \mathrm{vlp} \mathrm{mL}^{-1} \mathrm{~h}^{-1}$ ) than at the open sea station (mean $=0.14 \pm 0.03 \times 10^{6} \mathrm{vlp}$ $\mathrm{mL}^{-1} \mathrm{~h}^{-1}$ ) (Table 2; Fig. 2).

\section{Virus-mediated mortality of bacteria, fraction of lytical and lysogenic bacterial infection}

The virus-mediated mortality of bacterial standing stock (VMM) varied between 30.68 and $145.50 \%$ day $^{-1}$ (mean $=78.81 \pm 31.54 \%$ day $^{-1}$ ) at the coastal sea station, and between 50.68 and $78.81 \%$ day $^{-1}$ $\left(\right.$ mean $=63.75 \pm 8.80 \%$ day $\left.^{-1}\right)$ at the open sea station (Table 2). At both stations, maximum values were found in July. The percentage of lytically infected bacterial cells was slightly higher at the coastal station (mean $=25.56 \pm 12.75 \%)$ then at the open sea station $($ mean $=22.39 \pm 5.47 \%)($ Table 2; Fig. 3$)$. The highest mean value $(48.00 \%)$ was determined in February at the coastal station (depth $10 \mathrm{~m}$ ), and in July (33.01\%) at the open sea station (bottom layer). The percentage of lysogenic bacterial infection was low, with similar mean values at both studied stations $(3.20 \pm 3.02 \%$ at the coastal station and $3.14 \pm 1.94 \%$ at the open-sea station) (Table 2; Fig. 3).

\section{Release of organic carbon, nitrogen and phosphorus by viral lysis}

The amounts of organic carbon, nitrogen and phosphorus released by viral lysis varied significantly between stations $(t$ test, $\mathrm{p}<0.05)$, and were greater at the coastal station (mean values $=9.26 \pm 4.21 \mu \mathrm{g} \mathrm{C} \mathrm{L}{ }^{-1}$ day $^{-1}$, $1.85 \pm 0.84 \mu \mathrm{g} \mathrm{N} \mathrm{L}^{-1}$ day $^{-1}, 0.37 \pm 0.17 \mu \mathrm{g} \mathrm{P} \mathrm{L}^{1}$ day $^{-1}$ ) than at the open sea station (mean values $=3.80 \pm 0.60 \mu \mathrm{g} \mathrm{CL}^{-1} \mathrm{day}^{-1}, 0.76 \pm 0.12 \mu \mathrm{g} \mathrm{N} \mathrm{L}^{-1} \mathrm{day}^{-1}$, $0.15 \pm 0.02 \mu \mathrm{g} \mathrm{P} \mathrm{L}^{-1} \mathrm{day}^{-1}$ ) (Table 3).

\section{Discussion}

Since the investigated sites are located in the central Adriatic area, which is characterized by the different trophic conditions of the coastal and open sea waters [24, 
Table 2 Sampling depth and month, viral production, viral decay, viral turnover time, burst size (BS), percentage of lysogenic cells, percentage of lytically infected cells and virus-mediated mortality (VMM) at the investigated coastal and open-sea station (mean values \pm SD, where applicable

\begin{tabular}{|c|c|c|c|c|c|c|c|c|}
\hline Depth (m) & Month & $\begin{array}{l}\text { Viral production* } \\
\left(10^{6} \text { vlp } \mathrm{mL}^{-1} \mathrm{~h}^{-1}\right)\end{array}$ & $\begin{array}{l}\text { Viral decay } \\
\left(10^{6} \mathrm{vlp} \mathrm{mL}^{-1} \mathrm{~h}^{-1}\right)\end{array}$ & Turnover (h) & BS* $^{*}$ & Lysogeny (\%) & $\begin{array}{l}\text { Lytically infected } \\
\text { cells (\%) }\end{array}$ & VMM $^{*}(\%)$ \\
\hline \multicolumn{9}{|c|}{ Coastal station, $43^{\circ} 31^{\prime} 10^{\prime \prime N}, 16^{\circ} 22^{\prime} 52^{\prime \prime} E$} \\
\hline 0 & 10 & $0.94 \pm 0.16$ & $0.32 \pm 0.08$ & 17.49 & 27 & 0.00 & $34.52 \pm 3.78$ & $119.27 \pm 19.73$ \\
\hline 0 & 2 & $0.93 \pm 0.21$ & $0.30 \pm 0.01$ & 15.92 & 56 & 1.27 & $43.20 \pm 1.71$ & $71.22 \pm 16.12$ \\
\hline 0 & 6 & $0.33 \pm 0.07$ & $0.21 \pm 0.05$ & 39.80 & 52 & 1.32 & $17.28 \pm 1.14$ & $30.68 \pm 6.41$ \\
\hline 0 & 7 & $0.90 \pm 0.19$ & $0.26 \pm 0.08$ & 17.51 & 36 & 3.39 & $15.74 \pm 1.01$ & $71.14 \pm 15.19$ \\
\hline 10 & 10 & $1.00 \pm 0.16$ & $0.29 \pm 0.05$ & 14.81 & 65 & 1.70 & $15.34 \pm 3.03$ & $57.05 \pm 9.01$ \\
\hline 10 & 2 & $0.40 \pm 0.08$ & $0.36 \pm 0.07$ & 37.12 & 21 & 3.50 & $48.00 \pm 0.46$ & $79.94 \pm 15.12$ \\
\hline 17 & 6 & $0.69 \pm 0.05$ & $0.13 \pm 0.02$ & 15.90 & 45 & 1.03 & $15.72 \pm 4.29$ & $82.40 \pm 5.98$ \\
\hline 11 & 7 & $1.87 \pm 0.27$ & $0.25 \pm 0.03$ & 5.72 & 56 & 3.63 & $16.95 \pm 0.67$ & $145.40 \pm 20.74$ \\
\hline 35 & 10 & $0.45 \pm 0.08$ & $0.23 \pm 0.10$ & 37.14 & 25 & 4.59 & $12.66 \pm 1.06$ & $65.19 \pm 11.69$ \\
\hline 35 & 2 & $0.39 \pm 0.08$ & $0.33 \pm 0.05$ & 35.47 & 12 & 11.78 & $40.35 \pm 1.51$ & $80.55 \pm 3.03$ \\
\hline 35 & 6 & $0.32 \pm 0.08$ & $0.17 \pm 0.02$ & 39.40 & 45 & 2.96 & $24.46 \pm 0.76$ & $42.68 \pm 11.08$ \\
\hline 35 & 7 & $0.81 \pm 0.16$ & $0.17 \pm 0.05$ & 16.33 & 54 & 3.22 & $34.46 \pm 1.24$ & $100.21 \pm 0.27$ \\
\hline \multicolumn{9}{|c|}{ Open-sea station, $43^{\circ} 2^{\prime} 39^{\prime \prime} \mathrm{N}, 16^{\circ} 17^{\prime} 6^{\prime \prime} \mathrm{E}$} \\
\hline 0 & 2 & $0.41 \pm 0.09$ & $0.18 \pm 0.01$ & 25.71 & 53 & 3.48 & $28.60 \pm 6.53$ & $57.29 \pm 13.02$ \\
\hline 0 & 6 & $0.64 \pm 0.05$ & $0.18 \pm 0.03$ & 10.81 & 80 & 0.71 & $20.27 \pm 5.60$ & $62.95 \pm 3.25$ \\
\hline 0 & 7 & $0.15 \pm 0.06$ & $0.14 \pm 0.03$ & 43.89 & 18 & 6.28 & $21.65 \pm 3.90$ & $62.89 \pm 24.07$ \\
\hline 10 & 2 & $0.81 \pm 0.06$ & $0.17 \pm 0.02$ & 14.99 & 91 & 5.71 & $17.11 \pm 1.93$ & $62.09 \pm 4.57$ \\
\hline 15 & 6 & $0.96 \pm 0.08$ & $0.13 \pm 0.01$ & 7.16 & 101 & 0.98 & $19.09 \pm 0.33$ & $75.53 \pm 6.10$ \\
\hline 20 & 7 & $0.34 \pm 0.08$ & $0.10 \pm 0.01$ & 18.62 & 41 & 2.01 & $21.30 \pm 6.56$ & $65.82 \pm 15.98$ \\
\hline 100 & 2 & $0.32 \pm 0.03$ & $0.11 \pm 0.01$ & 26.98 & 49 & 4.06 & $24.37 \pm 8.18$ & $57.77 \pm 6.23$ \\
\hline 100 & 6 & $0.48 \pm 0.07$ & $0.13 \pm 0.01$ & 13.03 & 89 & 2.65 & $16.14 \pm 0.50$ & $50.68 \pm 7.06$ \\
\hline 100 & 7 & $0.30 \pm 0.08$ & $0.12 \pm 0.03$ & 22.72 & 36 & 2.42 & $33.01 \pm 1.81$ & $78.71 \pm 14.60$ \\
\hline
\end{tabular}

* Significance of differences between two stations, $\mathrm{p}<0.05$

$25,47-49]$, the differences in viral and bacterial abundance and activity are expected. Bacterial abundance was lower at the open than at the coastal sea station, which is consistent with the results previously found for the North [11, 13] and Mid Adriatic [25, 28]. Bacterial production followed a similar pattern to that of abundance, which is in accordance with previously published data for the same area [25], for the North Adriatic [13] and the Western Mediterranean Sea [16]. The abundance of marine viruses was significantly lower $(t$ test, $p<0.05)$ at the open-sea station than at the costal station, as previously described by Ordulj et al. [25]. A similar pattern was observed in the Northern Adriatic [13, 21, 22, 50]. It is known that viral and bacterial abundances change according to the productivity of the aquatic environment [7]. A higher abundance of marine bacteria is usually followed by a higher abundance of marine viruses, and thus, viral production [6].

The virus-to-bacteria ratio (VBR) was similar at both stations. VBR values are within the range previously determined for the central Adriatic [25]. The similarities in VBR values between the two investigated stations could be explained by the higher production of viruses and their higher decay at the coastal station compared to the open sea station. Parrika et al. [51] noted that in the open and offshore waters, in less productive waters generally, VBR values are higher than in the usual eutrophic coastal waters, mostly because of vivory (grazing by the HNF), adsorption by particulate matter, degradation by heat-labile organic matter, UV radiation and temperature. Since the coastal station in this study is not eutrophic, but rather mesotrophic [28], similarities in VBR are expected. Lower than average VBR values were observed at the coastal-sea station during February at the bottom, and July in the surface layer, which might have been caused by low temperature and high UV radiation, respectively. Lower than average VBR values were also observed at the open-sea station during the warmer part of the year, which could be the result of higher UV radiation exposure of the surface layer. It is known that marine viruses are susceptible to UV radiation, especially in the surface layer $[40,52,53]$. Additionally, low temperature 

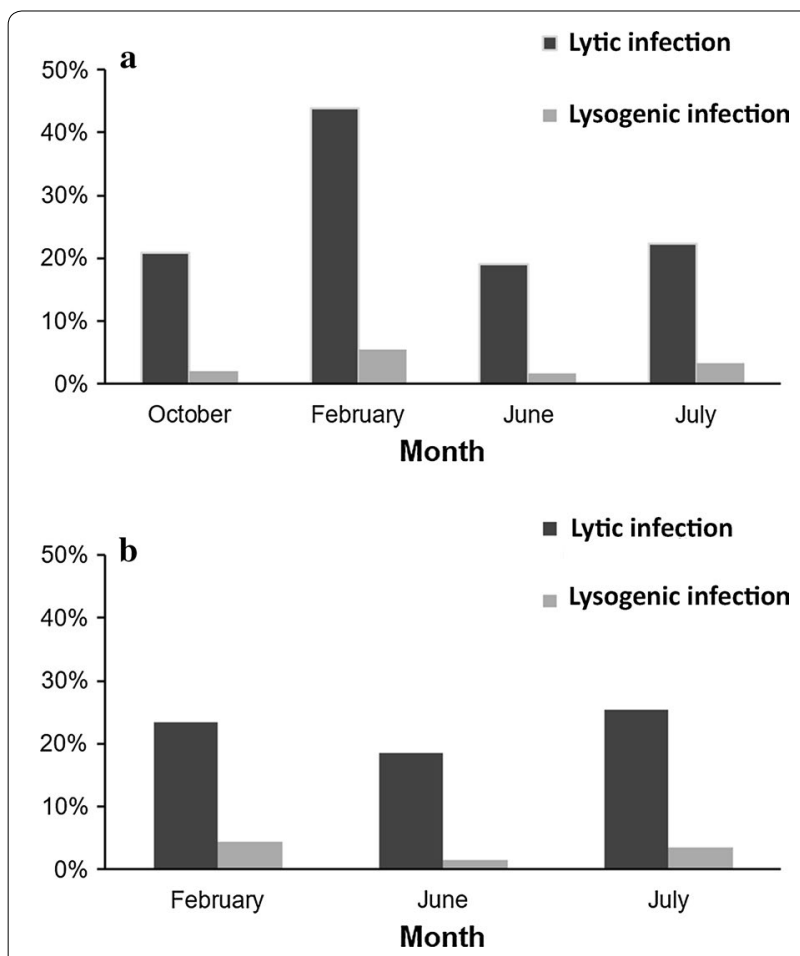

Fig. 3 Percentage of lytically infected and lysogenic bacteria in total bacterial abundance at the coastal (a) and open (b) sea stations

can affect virus-host interactions, which can result in less successful viral proliferation, and thus low abundances [54]. Furthermore, since viral abundance changes over the course of days and weeks, it is possible that temporal changes could substantially affect the VBR [55].

The virus dilution technique [34] has become the preferred method for determining the activity of marine viruses [36]. A dilution of viral density ensures the low occurrence of new phage infections and reduces possible viral losses due to new infection, predation and enzymatic degradation [34, 36]. Viral production showed the same pattern as viral abundance (Table 2; Fig. 2), and was higher at the coastal sea station. The highest values were observed at the depth of the thermocline during the warmer part of the year (June, July), at both investigated stations.

Viral production at the coastal sea station was within the range of data previously reported for the Gulf of Trieste [26], but was three-fold lower than the values estimated for the eutrophic area close to the river Po [13]. These results are not surprising, since the estuarine area of the river Po has a higher trophic level than Kaštela Bay, due to higher nutrient input from the river Po [56]. At the open sea station, viral production was similar to that found for the north-western Mediterranean [39], which was previously characterized as an oligotrophic area with low viral abundance [57].
At the studied stations, average bacterial turnover was $7 \mathrm{day}^{-1}$, while average viral turnover was $1 \mathrm{day}^{-1}$. In general, a bacterial community with lower density and lower bacterial turnover can sustain specific viral production, turnover and thus relatively high viral abundance because it can be more valuable to viruses, with a potential longer latent period, which results in more progeny per infected bacterial cell [58]. This is in accordance with our findings, i.e. higher BS at the open sea station ( $41 \pm 17$ for coastal and $62 \pm 29$ on open sea station). On the other hand, lower viral decay at the open sea station could also be one of the reasons for the higher virus abundance and equal average VBR value determined at both stations. We also need to mention that although the dilution technique applied for the estimation of viral production currently is the most reliable method, it is based on sample processing that can potentially lead to inaccurate estimates [51]. Additionally, while measuring viral production we did not consider that cyanobacterial phages could be present at both stations since the abundance of cyanobacteria there varies between $10^{3}$ and $10^{4} \mathrm{ml}^{-1}$ [59] and, therefore, cyanobacterial phages could affect the viral production estimates.

BS was slightly higher at the open-sea station, although BS usually decreases from eutrophic to oligotrophic areas $[11,13]$. Since a VBR value of 25 was determined for the open-sea area, relatively higher BS values allowed for a greater number of free viral particles in the water column. With higher BS values, average turnover time was shorter at the open-sea station than at the coastal station $(20.62 \pm 12.60-25.93 \pm 14.55 \mathrm{~h}$, respectively). It should be noted that turnover time in the northern Adriatic [13] was even shorter, which corresponds with the higher trophic state of that area, compared to the area studied here. BS was positively correlated with viral production at the open sea station $(\mathrm{r}=0.95, \mathrm{n}=9, \mathrm{p}<0.05)$. The maximum values for both investigated stations were determined at the depth of thermocline (Table 2). This is significant because the thermocline layer represents a barrier where nutrients are retained [60], making it more productive thus favouring higher viral production, and therefore higher burst size. Short turnover time and higher BS at the coastal and open-sea stations were followed by the highest values of viral production.

The results of viral decay were similar to the results determined for the mesotrophic and oligotrophic area of the north Adriatic basin [13]. Because viruses decayed more slowly than they were produced, viral abundance in the water column was positively affected. At the coastal and open-sea stations, viral decay accounted for $43.15 \pm 25.19$ and $36.34 \pm 21.91 \%$ of viral production, respectively, on average. The result for the opensea station in this study is slightly different from the data 
Table 3 Sampling depth and month, amounts of released dissolved organic carbon (DOC), nitrogen (DON) and phosphorus (DOP) at the investigated coastal and open-sea station

\begin{tabular}{|c|c|c|c|c|}
\hline Depth (m) & Month & $\mathrm{DOC}^{*}\left(\mu \mathrm{g} C \mathrm{~L}^{-1} \mathrm{day}^{-1}\right)$ & $\mathrm{DON}^{*}\left(\mu \mathrm{g} \mathrm{N} \mathrm{L}^{-1} \mathrm{day}^{-1}\right)$ & 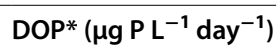 \\
\hline \multicolumn{5}{|c|}{ Coastal station, $43^{\circ} 31^{\prime} 10^{\prime \prime} \mathrm{N}, 16^{\circ} 22^{\prime} 52^{\prime \prime}$ E } \\
\hline 0 & 10 & $16.44 \pm 2.72$ & $3.29 \pm 0.54$ & $0.66 \pm 0.109$ \\
\hline 0 & 2 & $7.97 \pm 1.80$ & $1.59 \pm 0.36$ & $0.32 \pm 0.072$ \\
\hline 0 & 6 & $3.08 \pm 0.64$ & $0.62 \pm 0.13$ & $0.12 \pm 0.026$ \\
\hline 0 & 7 & $12.08 \pm 2.58$ & $2.42 \pm 0.52$ & $0.48 \pm 0.103$ \\
\hline 10 & 10 & $7.43 \pm 1.17$ & $1.49 \pm 0.23$ & $0.30 \pm 0.047$ \\
\hline 10 & 2 & $9.03 \pm 1.71$ & $1.81 \pm 0.34$ & $0.36 \pm 0.068$ \\
\hline 17 & 6 & $7.25 \pm 0.53$ & $1.45 \pm 0.11$ & $0.29 \pm 0.021$ \\
\hline 11 & 7 & $15.95 \pm 2.28$ & $3.19 \pm 0.46$ & $0.64 \pm 0.091$ \\
\hline 35 & 10 & $8.43 \pm 1.51$ & $1.69 \pm 0.30$ & $0.34 \pm 0.060$ \\
\hline 35 & 2 & $11.98 \pm 0.45$ & $2.40 \pm 0.09$ & $0.48 \pm 0.018$ \\
\hline 35 & 6 & $3.43 \pm 0.89$ & $0.69 \pm 0.18$ & $0.14 \pm 0.036$ \\
\hline 35 & 7 & $8.06 \pm 0.02$ & $1.61 \pm 0.00$ & $0.32 \pm 0.001$ \\
\hline \multicolumn{5}{|c|}{ Open-sea station, $43^{\circ} 31^{\prime} 10^{\prime \prime} \mathrm{N}, 16^{\circ} 22^{\prime} 52^{\prime \prime} \mathrm{E}$} \\
\hline 0 & 2 & $3.74 \pm 0.85$ & $0.75 \pm 0.17$ & $0.15 \pm 0.034$ \\
\hline 0 & 6 & $3.81 \pm 0.20$ & $0.76 \pm 0.04$ & $0.15 \pm 0.008$ \\
\hline 0 & 7 & $4.05 \pm 1.55$ & $0.81 \pm 0.31$ & $0.16 \pm 0.062$ \\
\hline 10 & 2 & $4.25 \pm 0.31$ & $0.85 \pm 0.06$ & $0.17 \pm 0.013$ \\
\hline 15 & 6 & $4.57 \pm 0.37$ & $0.91 \pm 0.07$ & $0.18 \pm 0.015$ \\
\hline 20 & 7 & $3.96 \pm 0.96$ & $0.79 \pm 0.19$ & $0.16 \pm 0.038$ \\
\hline 100 & 2 & $3.18 \pm 0.34$ & $0.64 \pm 0.07$ & $0.13 \pm 0.014$ \\
\hline 100 & 6 & $2.57 \pm 0.36$ & $0.51 \pm 0.07$ & $0.10 \pm 0.014$ \\
\hline 100 & 7 & $4.08 \pm 0.76$ & $0.82 \pm 0.15$ & $0.16 \pm 0.03$ \\
\hline
\end{tabular}

Values \pm SD

* Significance of differences between two stations, $p<0.05$

published by Bongiorni et al. [13], where viral decay only partially balanced viral production $(1.6 \%)$ at the oligotrophic open-sea station. The observed difference can be explained by two- to three-fold greater abundance of viruses in the water column, lower viral production, and higher production of bacteria at every investigated depth of the open-sea station in the middle Adriatic. Additionally, the vicinity of the mainland to the open-sea station can lead to a higher content of heat-labile and colloidal particles that can cause higher removal of viruses [40, 61]. By using the filtration based approach for the estimation of viral decay, we might have partially underestimated viral decay rates since bacteria, suspended matter and other organic molecules are removed during the process, and other physical factors such as UV radiation, were not considered either. However, we did observe different rates at the coastal and open sea stations, which were characterized by different trophic conditions [28]; therefore, our data can be considered, although they need to be confirmed by other approaches and methods of analysis.
VMM values were relatively high, which is in accordance with previously published data for the Adriatic and Mediterranean Sea [11, 16, 20, 26, 39]. The highest average value of VMM was observed in the thermocline layer for both investigated stations $(91.20 \pm 37.90 \%$ at the coastal and $67.81 \pm 6.94 \%$ at the open-sea station). These results indicate that viruses are active components of microbial ecosystems and play a significant role in shaping bacterial communities. Several reports have stated that VMM can match or even exceed the mortality of bacteria caused by bacterivores, primarily heterotrophic nanoflagellates (HNF), which are the main predators of bacteria $[4,8,9,62]$. According to our data, the removal rate of bacterial cells by viruses at the coastal-sea station ranged from 0.64 to $3.43 \times 10^{4}$ cells $\mathrm{mL}^{-1} \mathrm{~h}^{-1}$, with a mean value of $1.96 \pm 0.92 \times 10^{4}$ cells $\mathrm{mL}^{-1} \mathrm{~h}^{-1}$, which is two-fold lower than the mean rate of bacterial removal by HNF, as previously calculated by Šolić and Krstulović $[63,64]$. However, this research shows that viruses can remove a substantial part of the bacterial standing stock and that viruses, together with HNF grazing, 
generally play an important role in controlling the bacterial population. It is important to mention that in 1993, when grazing experiments were carried out by Šolić and Krstulović [63, 64], Kaštela Bay was characterised by a higher trophic level than when our research was conducted [65]. This suggests that HNF grazing levels could be lower today.

The highest value of lysogenic infection was determined at the coastal station in February, in the bottom layer (11.78\%), during low temperatures, although there was no statistically significant correlation between lysogeny and temperature. The highest value of lysogenic infection at the open-sea station was determined in July, at the surface $(6.28 \%)$, which could have been caused by higher exposure to UV radiation during sampling. These results suggest that viruses predominantly caused lytic rather than lysogenic infection, which is confirmed by the high percentage of lytically infected bacteria at the coastal and open-sea station (Fig. 3), as mentioned before. The lytic cycle prevails over the lysogenic cycle in marine ecosystems probably because the production of viruses during the lytic cycle is dependant on the rate of multiplication of the viral genome in the host cell, whereas the lysogenic cycle depends largely on the growth rate of the host [6]. Lysogeny is often the preferred strategy of viral replication in areas characterized by low bacterial abundance and production [6]. Various authors have suggested that in order to maintain the lytic cycle in the marine ecosystems, viral density should be at least $10^{4}$ viruses per $\mathrm{mL}$ $[15,48,58,66]$, and these conditions were found at the investigated stations. The percentage of lytically infected cells varies according to the trophic status of an area [4, 67]; therefore, higher values at a coastal sea station are expected.

The results for the amounts of organic carbon, nitrogen and phosphorus released by viral lysis fall within the range of those found in the northern Adriatic [13, 26], and are higher than the results reported for the oligotrophic Western Mediterranean [16, 39]. By lyzing a large proportion of bacterial cells per day, viruses have a substantial impact on nutrient cycling in the marine environment [4]. While bacterial grazing by HNF and ciliates transfers particulate organic matter to higher trophic levels, viral lysis transforms bacterial cells into a pool of particulate and dissolved organic matter, which then becomes available to bacterial cells and other microorganisms. Viruses could be a significant source of released dissolved organic carbon, nitrogen and phosphorus, particularly at the coastal station where average release rates were higher (Table 3). Furthermore, these results indicate the importance of viruses in nutrient cycling, especially of phosphorus, in P-limited [68] and oligotrophic areas such as the Adriatic Sea $[69,70]$.

\section{Conclusion}

This study provides insights into the viral dynamics in the waters of the central Adriatic. The viral production and decay rates were higher in the coastal waters due to the higher trophic condition than in the open waters. The viruses represent an extremely active component of the microbial food network and notably influence the bacterial community, since they are a significant cause of bacterial mortality in the studied area. These results suggest that viruses predominantly cause lytic rather than lysogenic infections in the central Adriatic. Ultimately, this study shows that viral activity is an important source of organic nutrients, especially phosphorus, in the P-limited Adriatic Sea.

\section{Abbreviations \\ VLP: virus-like particles; BS: burst size; VMM: virus-mediated mortality; VBR: virus-to-bacterium ratio; UV: ultra violet; HNF: heterotrophic nanoflagellates; DOC: dissolved organic carbon; DON: dissolved organic nitrogen; DOP: dis- solved organic phosphorus.}

\section{Authors' contributions}

$\mathrm{MO}$ and $\mathrm{NK}$ designed this study. MO conducted the experiments, sampling, and processed the samples. MO wrote the paper with great help of MŠ and SJ and other authors. DŠ performed the bacterial counts on Flow cytometer. All authors read and approved the manuscript.

\section{Author details}

${ }^{1}$ University Department of Marine Studies, University of Split, Ruđera Boškovića 37, Split, Croatia. ${ }^{2}$ Institute of Oceanography and Fisheries, P.O. Box 500, Split, Croatia.

\section{Acknowledgements}

We would like to thank prof. Peter Peduzzi for his valuable advice and help with the manuscript. We would also like to express our gratitude to Mr. Mate Pavlović and the crew of R/N Bios Dva for their assistance. This research was supported by the Croatian Science Foundation as part of the research project: IP-2014-09-4143 "Marine microbial food web processes in global warming perspective" (MICROGLOB).

\section{Competing interests}

The authors declare that they have no competing interests.

\section{Availability of data and materials}

The datasets generated and analysed during the current study are not publicly available due to copyright restrictions, but may be available from the corresponding author on reasonable request.

\section{Consent for publication}

All authors have read and approved the manuscript.

\section{Ethics approval and consent to participate}

The research involved no human subjects, human material or human data. Sampling was done on-board the BIOS Dva research vessel.

\section{Funding}

This research was supported by the Croatian Science Foundation as part of the research project: IP-2014-09-4143 "Marine microbial food web processes in global warming perspective" (MICROGLOB).

\section{Publisher's Note}

Springer Nature remains neutral with regard to jurisdictional claims in published maps and institutional affiliations. 
Received: 3 April 2017 Accepted: 26 October 2017

Published online: 02 November 2017

\section{References}

1. Thingstad TF, Heldal M, Bratbak G, Dundas I. Are viruses important partners in pelagic food webs? TREE. 1993;8(6):209-13.

2. Bratbak G, Thingstad F, Heldal M. Viruses and the microbial loop. Microb Ecol. 1994;28:209-21.

3. Fuhrman JA. Marine viruses and their biogeochemical and ecological effects. Nature. 1999;399:541-8.

4. Weinbauer MG. Ecology of prokaryotic viruses. FEMS Microbiol Rev. 2004;28:127-81.

5. Suttle CA. Viruses in the sea. Nature. 2005:437:356-61.

6. Jacquet S, Miki T, Noble RT, Peduzzi P, Wilhelm S. Viruses in aquatic ecosystems: important advancements of the last 20 years and prospects for the future in the field of microbial oceanography and limnology. Adv Ocean Limnol. 2010;1:71-101.

7. Sime-Ngando T. Environmental bacteriophages: viruses of microbes in aquatic ecosystems. Front Microbiol. 2014;5:355.

8. Fuhrman JA, Noble RT. Viruses and protists cause similar bacterial mortality in costal seawater. Limnol Oceanogr. 1995;40:1236-42.

9. Wommack KE, Colwell RR. Virioplankton: viruses in aquatic ecosystems. Microbiol Mol Biol Rev. 2000;64:2180-5.

10. Suttle CA. Marine viruses-major players in the global ecosystem. Nat Rev Microbiol. 2007;5:801-12

11. Weinbauer MG, Fuks D, Puskarić S, Peduzzi P. Distribution of viruses and dissolved DNA along a coastal trophic gradient in the Northern Adriatic Sea. Appl Environ Microbiol. 1993;59:4074-82.

12. Noble RT, Fuhrman JA. Rapid virus production and removal as measured with fluorescently labeled viruses as tracers. Appl Environ Microbiol. 2000:66(9):3790-7.

13. Bongiorni L, Magagnini M, Armeni M, Noble RT, Danovaro R. Viral production, decay rates, and life strategies along a trophic gradient in the north Adriatic. Appl Environ Microbiol. 2005;71:6644-50.

14. Malits A, Christaki U, Obernosterer I, Weinbauer MG. Enhanced viral production and virus-mediated mortality of bacterioplankton in a natural iron-fertilized bloom event above the Kerguelen Plateau. Biogeosciences. 2014;11:6841-53

15. Weinbauer MG, Suttle CA. Potential significance of lysogeny to bacteriophage production and bacterial mortality in coastal waters of the Gulf of Mexico. Aquat Microb Ecol. 1996;62:4374-80.

16. Weinbauer MG, Brettar I, Hofle MG. Lysogeny and virus-induced mortality of bacterioplankton in surface, deep, and anoxic marine waters. Limnol Oceanogr. 2003:48(4):1457-65.

17. Paul JH, Weinbauer MG. Detection of lysogeny in marine environments. MAVE. 2010:4:30-3.

18. Knowles B, Silveira CB, Bailey BA, Barott K, Cantu VA, Cobián-Güemes AG Coutinho FH, Dinsdale EA, Felts B, Furby KA, George EE. Lytic to temperate switching of viral communities. Nature. 2016:531(7595):466-70.

19. Wigington $\mathrm{CH}$, Sonderegger $\mathrm{D}$, Brussard $\mathrm{CPD}$, Buchan $A$, Finke JF, Fuhrman JA, Lennon JT, Middelboe M, Suttle CA, Stock C, Wilson WH, Wommack KE, Wilhelm SW, Weitz JS. Re-examination of the relationship between marine virus and microbial cell abundances. Nat Microbiol. 2016;1:15024

20. Weinbauer MG, Fuks D, Puskaric S, Peduzzi P. Diel, seasonal and depth related variability of viruses and dissolved DNA in the Northern Adriatic Sea. Microb Ecol. 1995:30:25-41.

21. Weinbauer MG, Peduzzi P. Frequency, size and distribution of bacteriophages in different marine bacterial morphothypes. Mar Ecol Prog Ser. 1994:108:11-20.

22. Weinbauer MG, Peduzzi P. Significance of viruses versus heterotrophic nanoflagellates for controlling bacterial abundance in the northern Adriatic Sea. J Plankton Res. 1995;17:1851-6.

23. Corinaldesi C, Crevatin E, Del Negro PF, Marini M, Russo A, Fonda-Uman S, Danovaro R. Large-scale spatial distribution of virioplankton in the Adriatic Sea: testing the trophic state control hypothesis. Appl Environ Microbiol. 2003;69:2664-73.
24. Krstulović N, Šolić M, Šantić D, Maršić-Lučić J, Ordulj M, Šestanovié S Microbial community structure in two anchialine caves on Mljet Island (Adriatic Sea). Acta Adriat. 2013:54(2):183-98.

25. Ordulj M, Krstulović N, Šantić D, Jozić S, Šolić M. Distribution of marine viruses in the Central and South Adriatic Sea. Medit Mar Sci. 2015;16(1):65-72

26. Karuza A, Del Negro P, Crevatin E, Fonda Umani S. Viral production in the Gulf of Trieste (Northern Adriatic Sea): preliminary results using different methodological approaches. J Exp Mar Biol Ecol. 2010:383:96-104.

27. Karuza A, Umani SF, Del Negro P. The (un) coupling between viruses and prokaryotes in the Gulf of Trieste. Estuar Coast Shelf Sci. 2012;115:87-97.

28. Šantić D, Krstulović $N$, Šolić M, Ordulj M, Kušpilić G. Dynamics of prokaryotic picoplankton community in the central and southern Adriatic Sea (Croatia). Helgol Mar Res. 2012;67(3):471.

29. Marie D, Partensky F, Jacquet S, Vaulot D. Enumeration and cell cycle analysis of natural populations of marine picoplankton by flow cytometry using the nucleic acid stain SYBR green I. Appl Environ Microbiol. 1997;63:186-93.

30. Fuhrman JA, Azam F. Bacterioplankton secondary production estimates for coastal waters of British Columbia, Antarctica, and California. Appl Environ Microbiol. 1980;39:1085-95.

31. Riemann B, Bjmnsen PK, Newell S, Fallon R. Calculation of cell production of coastal marine bacteria based on measured incorporation of $\left[{ }^{3} \mathrm{H}\right]$-thymidine. Limnol Oceanogr. 1987;32:471-6.

32. Noble RT, Fuhrman JA. Use of SYBR Green I for rapid epifluorescence counts of marine viruses and bacteria. Aquat Microb Ecol. 1998:14:113-8.

33. Wen K, Ortmann AC, Suttle CA. Accurate estimation of viral abundance by epifluorescence microscopy. Appl Environ Microbiol. 2004;70(7):3862-7.

34. Wilhelm SW, Brigden SM, Suttle CA. A dilution technique for the direct measurement of viral production: a comparison in stratified and tidally mixed coastal waters. Microb Ecol. 2002;43:168-73.

35. Luef B, Luef F, Peduzzi P. Online program "VIPCAL" for calculating lytic viral production and lysogenic cell based on viral reduction approach. Environ Microbiol Rep. 2009;1:78-85.

36. Weinbauer MG, Rowe JM, Wilhelm SW. Determining rates of virus production in aquatic systems by the virus reduction approach. MAVE. $2010 \cdot 1 \cdot 1-8$

37. Wells LE, Deming JW. Significance of bacterivory and viral lysis in bottom waters of Franklin Bay, Canadian Arctic, during winter. Aquat Microb Ecol. 2006;43(3):209-21.

38. Middelboe M, Lyck PG. Regeneration of dissolved organic matter by viral lysis in marine microbial communities. Aquat Microb Ecol. 2002;27(2):187-94.

39. Boras A, Montserrat Sala M, Vasquez-Dominugues E, Weinbauer MG, Vaque D. Annual changes of bacterial mortality due to viruses and protest in an oligotrophic coastal environment (NW Mediterranean). Environ Microbiol. 2009;11(5):1181-93.

40. Noble RT, Fuhrman JA. Virus decay and it's causes in coastal waters. Appl Environ Microbiol. 1997;63:77-83.

41. Ortmann AC, Lawrence JE, Suttle CA. Lysogeny and lytic viral production during a bloom of the cyanobacterium Synechococcus spp. Microb Ecol. 2002:43(2):225-31.

42. Lee S, Fuhrman JA. Relationships between biovolume and biomass of naturally derived marine bacterioplankton. Appl Environ Microbiol. 1987;53:1298-303.

43. Simon M, Azam F. Protein content and protein synthesis rates of planktonic bacteria. Mar Ecol Prog Ser. 1989;51:201-13.

44. Fukuda R, Ogawa H, Nagata T, Koike I. Direct determination of carbon and nitrogen contents of natural bacterial assemblage in marine environments. Appl Environ Microbiol. 1998;64:3352-8.

45. Gundersen K, Heldal M, Norland S, Purdie D, Knap A, Elemental C. N, and $P$ cell content of individual bacteria collected at the Bermuda Atlantic time-series study (BATS) site. Limnol Oceanogr. 2002;47:525-1530.

46. Cole JJ, Pace ML, Caraco NF, Steinhart GS. Bacterial biomass and cell size distributions in lakes: more and larger cells in anoxic waters. Limnol Oceanogr. 1993;38:1627-32

47. Krstulović N, Šolić M, Marasović I. Relationship between bacteria, phytoplankton and heterotrophic nanoflagellates along the trophic gradient. Helgöland Meeresuntersuch. 1997;51:433-43. 
48. Šolić M, Krstulović N, Vilibić I, Bojanié N, Kušpilicé G, Šestanović S, Šantić D, Ordulj M. Variability in the bottom-up and top-down control of bacteria on trophic and temporal scale in the middle Adriatic Sea. Aquat Microb Ecol. 2009;58:15-29.

49. Šantić $D$, Šestanović S, Šolić M, Krstulović N, Kušpilić G, Ordulj M, Ninčević Gladan Ž. Dynamics of the picoplankton community from coastal waters to the open sea in the central Adriatic. Medit Mar Sci. 2014;15(1):179-88.

50. Stopar D, Cerne A, Zeigman M, Poljsak-Prijatelj M, Turk V. Viral abundance and a high proportion of lysogens suggest that viruses are important members of the microbial community in the Gulf of Trieste. Microb Ecol. 2004:47:1-8.

51. Parikka KJ, Le Romancer M, Wauters N, Jacquet S. Deciphering the virus-to-prokaryote ratio (VPR): insights into virus-host relationships in a variety of ecosystems. Biol Rev. 2017;92(2):1081-100.

52. Jacquet $\mathrm{S}$, Bratbak $\mathrm{G}$. Effects of ultraviolet radiation on marine virusphytoplankton interactions. FEMS Microbiol Ecol. 2003;44(3):279-89.

53. Wilhelm SW, Jeffrey WH, Dean AL, Meador J, Pakulski JD, Mitchell DL. UV radiation induced DNA damage in marine viruses along a latitudinal gradient in the southeastern Pacific Ocean. Aquat Microb Ecol. 2003;31(1):1-8.

54. Mojica KD, Brussaard CP. Factors affecting virus dynamics and microbial host-virus interactions in marine environments. FEMS Microbiol Ecol. 2014;89(3):495-515

55. Siokou-Frangou I, Christaki U, Mazzocchi MG, Montresor M, Ribera d'Alcalá M, Vaqué D, Zingone A. Plankton in the open Mediterranean Sea: a review. Biogeosciences. 2010;7(5):1543-86.

56. Degobbis D, Precali R, Ivančić I, Smodlaka N, Fuks D, Kveder S. Long-term changes in the northern Adriatic ecosystem related to anthropogenic eutrophication. Int J Environ Pollut. 2000;13:495-533.

57. Alonso MC, Jimenez-Gomez F, Rodriguez J, Borrego JJ. Distribution of virus-like particles in an oligotrophic marine environment (Alboran Sea, Western Mediterranean). Microb Ecol. 2001;42:407-15.

58. Abedon ST, Herschler TD, Stopar D. Bacteriophage latent-period evolution as a response to resource availability. Appl Environ Microbiol. 2001;67:4233-41.
59. Šantić D, Krstulović N, Šolić M, Kušpilić G. Distribution of Synechococcus and Prochlorococcus in the central Adriatic Sea. Acta Adriat. 2011;52(1):101-14.

60. George T, George P, Costas D, Theodorou A. Assessing marine ecosystem response to nutrient inputs. Mar Pollut Bull. 2001;43(7):175-86.

61. Wilhelm SW, Weinbauer MG, Suttle CA, Jeffrey WH. The role of sunlight in the removal and repair of viruses in the sea. Limnol Oceanogr. 1998;43(4):586-92.

62. Guixa-Boixereu N, Vaqué D, Gasol JM, Sánchez-Cámara J, Pedrós-Alió C. Viral distribution and activity in Antarctic waters. Deep Sea Res Pt II. 2002:49(4):827-45.

63. Šolić M, Krstulović N. Role of predation in controlling bacterial and heterotrophic nanoflagellate standing stocks in the coastal Adriatic Sea: seasonal patterns. Mar Ecol Prog Ser. 1994;114:219-35.

64. Šolić M, Krstulović N. Bacterial carbon flux through the microbial loop in Kaštela Bay (Adriatic Sea). Ophelia. 1995;41:345-60.

65. Šolić M, Krstulović N, Kušpilić G, Ninčević Gladan Ž, Bojanić N, Šestanović $\mathrm{S}$, Šantić D, Ordulj M. Changes in microbial food web structure in response to changed environmental trophic status: a case study of the Vranjic Basin (Adriatic Sea). Mar Environ Res. 2010;70:239-49.

66. Wilcox RM, Fuhrman JA. Bacterial viruses in coastal seawater: lytic rather than lysogenic production. Mar Ecol Prog Ser. 1994;114:35-45.

67. Ackermann HW, DuBow MS. Viruses of Prokaryotes. Vol. I. General properties of bacteriophages. Boca Raton: CRC Press Inc; 1987.

68. Riemann L, Holmfeldt K, Titelman J. Importance of viral lysis and dissolved DNA for bacterioplankton activity in a P-limited estuary, northern Baltic Sea. Microb Ecol. 2009;57:286-94.

69. Vukadin I, Stojanoski L. Phosphorus versus nitrogen limitation in the middle Adriatic Sea. Rapport du 36e Congrès de la Commission Internationale pour l'Exploration Scientifique de la mer Mediterranee. 2001;36:174.

70. Šolić M, Krstulovié N, Šantić D, Šestanović S, Ordulj M, Bojanić N, Kušpilić G. Structure of microbial communities in phosphorus-limited estuaries along the eastern Adriatic coast. J Mar Biol Assoc UK. 2015;95:1565-78.

\section{Submit your next manuscript to BioMed Central and we will help you at every step:}

- We accept pre-submission inquiries

- Our selector tool helps you to find the most relevant journal

- We provide round the clock customer support

- Convenient online submission

- Thorough peer review

- Inclusion in PubMed and all major indexing services

- Maximum visibility for your research

Submit your manuscript at www.biomedcentral.com/submit
() Biomed Central 